\title{
PERSEPSI MASYARAKAT TERHADAP TRANSPORTASI PUBLIK TRANS SARBAGITA DI PROVINSI BALI
}

\author{
Ni Made Firayanti Pratiwi ${ }^{1 *}$, Luh Indrayani ${ }^{2}$, Kadek Rai Suwena ${ }^{3}$ \\ 1,2,3 Afiliasi, Kota - Negara
}

\section{A R T I C L E I N F O}

Article history:

Received 1 May 2020

Received in revised form 30 May 2020

Accepted 5 June 2020

Available online 29 June 2020

Kata Kunci:

Persepsi, Trans Sarbagita

Transportasi Publik,

Kemacetan

Keywords:

Perception, Trans Sarbagita, Public Transportation,

Congestion

\begin{abstract}
A B S T R A K
Tujuan dari penelitian ini yaitu untuk mengetahui persepsi masyarakat terhadap keberadaan transportasi publik Trans Sarbagita. Jenis penelitian ini yaitu penelitian deskriptif dengan pendekatan kualitatif untuk mendeskripsikan mengenai persepsi masyarakat terhadap trasnportasi publik Trans Sarbagita di Provinsi Bali. Populasi dalam penelitian ini yaitu seluruh masyarakat yang tinggal di Daerah Sarbaguta dengan sampel yang digunakan sebanyak 400 responden yang dicari menggunakan rumus slovin. Metode pengumpulan data yang digunakan yaitu menggunakan kuesioner dan wawancara. Teknik analisis data yang digunakan dalam penelitian ini adalah analisis deskriptif. Hasil penelitian menunjukkan bahwa persepsi masyarakat dari dimensi kinerja memperoleh skor 10.238 termasuk ke dalam kategori baik. Dimensi pelayanan memperoleh skor 5.850 termasuk ke dalam kategori baik. Dimensi keandalan memperoleh skor 5.774 termasuk ke dalam kategori baik. Dimensi karakteristik produk memperoleh skor 2.988 termasuk ke dalam kategori baik. Dimensi kesesuaian dengan spesifikasi memeproleh skor 2.819 termasuk ke dalam kategori baik, sedangkan dari dimensi hasil memperoleh skor 5.075 termasuk ke dalam kategori kurang baik.
\end{abstract}

\section{A B S T R A C T}

This study aimed at determining public perceptions towards the existence of Trans Sarbagita public transportation. The type of the research was descriptive study with a qualitative approach to describe the public perception of Trans Sarbagita public transportation in the Bali Province. The population in this study were all people living in the Sarbaguta Region with a sample of 400 respondents who were searched using the Slovin formula.Data collection methods used were questionnaires and interview. The data analysis technique used in this research is descriptive analysis. Based on the results of the study, public perceptions of the performance dimension gained a score of 10,238 which categorized as good. The service dimension was categorized as good since it received a score of 5,850. The reliability dimension obtained a score of 5,777 which considered as good. The dimensions of product characteristics earned a score of 2,988 it was categorized as good. Dimensions of conformity with specifications was categorized as good. It obtained a score of 2,819, while the dimensions of the results obtained a score of 5,075 which categorized as below average.

\footnotetext{
* Corresponding author.

E-mail : firayantipratiwi12@gmail.com (Ni Made Firayanti Pratiwi)
} 


\section{Pendahuluan}

Salah satu hal yang memegang peran yang sangat penting di dalam pembangunan dan kemajuan suatu bangsa yaitu pengembangan sarana dan prasarana. Pengembangan sarana dan prasarana dapat dilakukan dengan peningkatan infrastruktur yang baik di wilayah tersebut dan juga dengan meningkatkan prasarana transportasi yang handal dan terintegrasi. Transportasi memiliki peranan yang sangat penting bagi berkembanganya suatu kota karena transportasi dinilai sebagai pendukung kegiatan ekonomi disuatu kota. Menurut Tamin (1995), transportasi memiliki peran untuk mengarahkan pembangunan di daerah perkotaan dan sebagai prasarana dalam pergerakan manusia dan atau barang yang timbul karena adanya kegiatan di daerah perkotaan tersebut, serta untuk mendukung pergerakan manusia dan barang.Menurut Adisasmita(2011), transportasi berarti suatu tindakan atau kegiatan untuk mengangkut atau memindahkan muatan seperti barang dan orang dari tempat asal ke tempat tujuan.

Seiring berjalannya waktu, semakin bertambahnya jumlah penduduk menyebabkan semakin banyaknya transportasi yang diperlukan oleh masyarakat. Dengan keberadaan transportasi yang kian hari semakin meningkat maka volume kendaraan di jalanan juga akan semakin meningkat. Volume kendaraan yang semakin meningkat di jalanan akan mengakibatkan kemacetan pada daerah tersebut apalagi untuk kota-kota besar yang memang merupakan kota bisnis dan pariwisata termasuk Bali. Kemacetan lalu lintas yang kerap terjadi di Bali tentu saja merugikan masyarakat sekitar. Kegiatan dari masyarakat tersebut menjadi terhambat karena kemacetan tersebut.

Kemacetan disebabkan oleh semakin banyaknya volume kendaraan. Volume kendaraan di Bali semakin hari semakin meningkat khususnya di daerah Bali Selatan. Masalah kemacetan yang sedang dialami di Provinsi Bali, khususnya daerah Bali Selatan berhasil menyita perhatian pemerintah. Pemerintah yang juga menyadari hal tersebut tentu saja tidak hanya tinggal diam dan melakukan upaya meminimalisir masalah tersebut. Pemerintah Bali memiliki program untuk meminimalisir kemacetan yang terjadi seperti membangun ruas jalan baru seperti jalan Tol di atas laut yang kini diberi nama Tol Bali Mandara, membangunan Underpass Simpang Dewa Ruci serta membuat program transportasi publik yang diberi nama Trans Sarbagita. Trans Sarbagita merupakan transportasi publik yang berjenis bus rapid transit (BRT).

Singkatan dari Sarbagita itu sendiri yaitu Denpasar, Badung, Gianyar dan Tabanan. Dasar hukum penyelenggaran Trans Sarbagita ialah UU Nomor 22 Tahun 2009 tentang Lalu Lintas dan Angkutan Jalan, PERDA Provinsi Bali No. 16 Tahun 2009 Tentang Rencana Tata Ruang Wilayah (RTRW) Provinsi Bali, PERDA Provinsi Bali No. 4 Tahun 2016 Tentang Penyelenggaraan Lalu Lintas dan Angkutan Jalan, MoU Kemenhub. dengan Pemprov. Bali dan Pemerintah Kab./Kota SARBAGITA tanggal 6 Desember 2010 tentang Perencanaan Pembangunan, pengembangan dan peningkatan Pelayanan Angkutan Umum di Wilayah SARBAGITA, dan MoU Gubernur Bali dengan Walikota/Bupati di wilayah SARBAGITA Tanggal 21 Mei 2018 tentang Pelayanan Angkutan Umum di Wilayah Denpasar, Badung, Gianyar dan Tabanan (SARBAGITA).

Sarbagita diluncurkan untuk digunakan oleh seluruh kalangan masyarakat tanpa membedakan status sosial maupun perekonomiannya. Sejalan dengan penelitian Sihotang (2015), bahwa masyarakat dalam memilih moda transportasi tidak dipengaruhi oleh latar sosial ekonomi. Jadi tidak hanya masyarakat yang memiliki perekonomian rendah atau tinggi saja namun semua kalangan juga dapat memakai. Berdasarkan Keputusan Gubernur Bali Nomor 1186/03-F/HK/2010 Tentang Penetapan Jaringan Trayek Angkutan Umum Trans Sarbagita, Trayek utama untuk Trans Sarbagita terdiri dari 17 trayek dan untuk trayek cabang hanya ada 1 trayek. Dengan banyaknya trayek yang dimiliki, diharapkan dapat membantu masyarakat khususnya di daerah Sarbagita tersebut dalam urusan transportasi. Dengan beralihnya masyarakat ke transportasi publik dapat mengurangi kemacetan lalu lintas. Dengan cara seperti itu, pemerintah sangat berharap agar program yang diluncurkannya tidak akan sia-sia dan dapat bermanfaat bagi masyarakat. Jadi, masyarakat sekitar dapat menggunakan transportasi publik tersebut dengan baik sehingga diharapkan penumpang yang diangkut oleh Trans Sarbagita juga banyak setiap harinya.

Berdasarkan data dari Dinas Perhubungan Provinsi Bali UPT. Trans Sarbagita, pada tahun 20142016, jumlah penumpang dari Trans Sarbagita mengalami kenaikan setiap harinya, namun pada tahun 2017 penumpang dari Trans Sarbagita mengalami penuruan setiap harinya. Penumpang Trans Sarbagita mulai mengalami penuruan pada tahun 2017, karena diduga mulai bermunculannya transportasi berbasis online seperti grab dan gojek. Kemudian pada tahun 2018, penumpang dari Trans Sarbagita mengalami penurunan yang sangat drastis dari tahun sebelumnya. Penurunan minat masyarakat terhadap transportasi publik menurut penelitian Surung, Wulandari \& Arka (2013) yaitu salah satunya adalah kurangnya armada angkutan pengumpan yang mengakibatkan Trans Sarbagita tidak dapat mencapai lokasi-lokasi wilayah tempat tinggal untuk mengurangi penggunaan transportasi pribadi.Sejalan dengan hal tersebut Putra (2016) dalam penelitiannya menyatakan bahwa aksesibilitas halte penjemputan masih rendah dan 
masyarakat Bali khususnya masyarakat yang tinggal di Daerah Sarbagita tergolong malas untuk berjalan kaki menuju ke halte terdekat.

Penurunan minat dari masyarakat terhadap Trans Sarbagita tersebut membuat pemerintah melakukan kebijakan baru, seperti perubahan tarif Trans Sarbagita. Untuk tarif penumpang Trans Sarbagita pada mulanya di patok dengan harga Rp3.500,00 untuk penumpang dari kalangan umum dan Rp2.500,00 untuk penumpang dari kalangan pelajar/ mahasiswa. Namun pada tahun 2019, berdasarkan Peraturan Gubernur Bali Nomor 112 tahun 2018 tentang Tarif Penumpang Angkutan Umum Trans Sarbagita Di Provinsi Bali, tarif Trans Sarbagita tersebut berubah menjadi Rp3.500,00 untuk penumpang dari kalangan umum dan gratis untuk penumpang dari kalangan pelajar/mahasiswa. Hal demikian juga disampaikan oleh Utama \& Handayeni (2019) bahwa tarif dari Trans Sarbagita berpengaruh besar terhadap peningkatan penggunaan Trans Sarbagita.

Kebijakan baru tersebut dibuat oleh pemerintah agar antusias masyarakat terhadap Trans Sarbagita bertambah, karena dari awal munculnya Trans Sarbagita itu sendiri dari tahun 2011 hingga sekarang kemacetan yang terjadi di daerah Bali Selatan bukan semakin berkurang melainkan semakin meningkat. Perkembangan program Bus Trans Sarbagita dirasa sangat lamban karena pengaruh perilaku dan budaya masyarakat Bali yang sudah terbiasa bepergian menggunakan kendaraan pribadi, sehingga mempengaruhi minat masyarakat terhadap penggunaan Bus Trans Sarbagita tersebut. Minat masyarakat terhadap penggunaan Bus Trans Sarbagita juga semakin rendah karena tidak adanya jaminan ketepatan waktu layanan dari Bus tersebut (Putra, 2016).

Efektivitas Bus Trans Sarbagita berdasarkan ketepatan waktu terbilang sangat tidak efektif, karena keberangkatan Bus Trans Sarbagita yaitu 1 jam sekali, sehingga masyarakat menunggu terlalu lama dan masyarakat lebih memilih menggunakan kendaraan pribadi (Wulandari \& Sudiana, 2011). Bus Trans Sarbagita dinilai menambah kemacetan karena ukuran kendaraan tersebut besar, namun penumpang yang dibawa minim serta jalur khusus untuk Trans Sarbagita itu sendiri tidak ada, sehingga Trans Sarbagita hanya menambah volume kendaraan di jalanan. Hal tersebut sejalan dengan hasil penelitian yang dilakukan oleh Tunjungsari, Setiawan, Wijaya, Tonglo, \& Apriawan (2019) menyatakan bahwa sempitnya ruas jalan di Daerah Sarbagita menyebabkan transportasi publik Trans Sarbagita menambah kemacetan di jalanan. Selain hasil penelitian tersebut, penelitian yang dilakukan oleh Widhyastuti, Pascarani, \& Yudharta(2016)juga menambahkan bahwa dengan ukuran bus Trans Sarbagita yang sangat besar, tidak akan menjangkau wilayah yang sempit apalagi dengan keadaan ruas jalanan di Daerah Sarbagita yang tergolong sempit. Hasil penelitian Budianayasa \& Wairocana (2018) juga sejalan dengan pernyataan tersebut yang menyampaikan bahwa kurang adanya jalur khusus untuk Trans Sarbagita karena jalanan umum tergolong sempit.

Dari uraian tersebut maka muncul berbagai persepsi masyarakat mengenai Trans Sarbagita.MenurutAssael(2001),persepsi adalah bahan yang sangat penting untuk dipahami berkaitan dengan aktivitasnya terhadap suatu produk dan menjadi indikator seberapa jauh produk tersebut sukses di pasaran dengan melihat respon yang ditunjukkan oleh konsumen terhadap produk tersebut. Terdapat beberapa dimensi yang mempengaruhi persepsi manusia terhadap suatu objek yaitu pertama, kinerja melibatkan karakteristik operasional dari objek tersebut. Kedua ,pelayanan merupakan suatu tindakan yang dapat diberikan oleh objek atau tempat tersebut kepada konsumen. Ketiga, ketahanan merupakan kemampuan suatu produk untuk bertahan atau daya tahan dari suatu produk. Keempat, keandalanmerupakan konsistensi dari kinerja yang dihasilkan suatu produk dari satu pembelian ke pembelian berikutnya. Kelima, karakteristik produk merupakan inovasi yang bisa diberikan oleh suatu produk untuk membedakan produk tersebut dengan produk lainnya.Keenam, kesesuaian dengan spesifikasimerupakan pandangan mengenai kualitas proses manufaktur sesuai dengan spesifikasi yang telah ditentukan dan telah teruji. Ketujuh, hasil merupakan hasil akhir yang dirasakan dari adanya produk tersebut.

Dalam penelitian ini menggunakan teori dari Assael namun dimensi ketahanan tidak digunakan karena tidak sesuai dengan objek penelitian yang akan diteliti.Tujuan dari penelitian ini yaitu untuk mengetahui bagaimana persepsi masyarakat terhadap transportasi publik Trans Sarbagita di Provinsi Bali ditinjau dari berbagai dimensi persepsi.

\section{Metode}

Jenis penelitian ini yaitu menggunakan penelitian deskriptif dengan pendekatan kualitatif. Penelitian deskriptif dilakukan untuk mendeskripsikan mengenai persepsi masyarakat terhadap trasnportasi publik Trans Sarbagita di Provinsi Bali. Penelitian ini dilakukan di daerah Denpasar, Badung, Gianyar dan Tabanan khususnya daerah yang terkena trayek atau rute perjalanan Trans Sarbagita. 
Populasi yang digunakan dalam penelitian ini adalah seluruh masyarakat yang tinggal di Daerah Sarbagita dengan sampel sebanyak 400 responden yang dicari menggunakan rumus slovin. Metode penentuan sampel yaitu menggunakan proportional random sampling. Setelah dihitung menggunakan rumus maka diperoleh 105 responden dari Kabupaten Badung, 147 responden dari Kota Denpasar, 79 responden dari Kabupaten Gianyar dan 69 responden dari Kabupaten Tabanan. Setelah sampel diambil pada masing-masing kabupaten atau kota secara proporsional yaitu pengambilan sampel dengan memperhatikan unsur dalam populasi penelitian, maka pengambilan dilanjutkan dengan cara randomisasi atau secara acak dengan mengikuti kriteria dari sampel yaitu masyarakat yang tinggal di daerah Denpasar, Badung, Gianyar dan Tabanan yang belum pernah menggunakan transportasi publik Trans Sarbagita.

Penelitian ini menggunakan tipe penelitian deskriptif dengan pendekatan kualitatif, dimana dalam penelitian ini data yang diperoleh dalam bentuk tulisan dan juga angka yang dianalisis kemudian dipaparkan, digambarkan dan disesuaikan dengan kenyataan, lalu dapat dijadikan dasar dalam penarikan kesimpulan. Sumber data yang digunakan dalam penelitian ini yaitu data primer berupa kuesioner dan hasil wawancara sehingga dapat diperoleh jawaban secara langsung dari masing-masing responden serta data sekunder yang berupa data dari Dishub Provinsi Bali UPT. Trans Sarbagita dan Peraturan-peraturan tentang Trans Sarbagita. Metode pengumpulan data yang digunakan dalam penelitian ini yaitu dengan kuesioner dan juga wawancara. Dimana kuesioner tersebut berisikan skala likert yang terdiri dari 5 skor, dengan skor 1 merupakan kategori sangat negatif hingga skor 5 merupakan kategori sangat positif. Sebelum kuesioner disebarkan kepada responden maka kuesioner tersebut diuji terlebih dahulu menggunakan uji validitas dan uji reliabilitas menggunakan SPSS 20.0 for windows.Instrumen kuesioner tersebut dikatakan valid apabila koefisien korelasi antar butir lebih besar dari $r$ tabel dengan tingkat kesalahan alpha 0,05. Sedangkan dikatakan reliabel jika suatu variabel mampu atau memiliki nilai cronbanch'c alpha> dari 0,60.

Teknik analisis data yang digunakan dalam penelitian ini adalah analisis deskriptif untuk mendeskriptifkan persepsi masyarakat terhadap transportasi publik Trans Sarbagita di Provinsi Bali. Adapun langkah-langkah dalam analisis deskriptif menurut Irianto (2004), yaitu. Menentukan skor terendah dan skor tertinggi dari keseluruhan alternatif jawaban. Rumus yang digunakan untuk menentukan skor tertinggi dan skor terendah yaitu skor tertinggi dapat dicari dengan mengalikan nilai tertinggi dengan jumlah pertanyaan dan jumlah responden. Begitu pula sebaliknya untuk mencari skor terendah. Dimana nilai tertinggi merupakan lima dan nilai terendah merupakan satu. Kemudian menentukan interval persepsi masyarakat di Provinsi Bali (Daerah Sarbagita) dengan rumus untuk mencari interval adalah skor tertinggi dikurangi skor terendah dibagi dengan kategori. Kategori yang digunakan dalam penelitian ini yaitu berjumlah lima kategori.

\section{Hasil dan pembahasan}

\section{Hasil Penelitian}

Berdasarkan hasil analisis data yang telah penguji lakukan dengan penyebaran kueioner, maka hasil dari dimensi kinerja dapat dilihat pada tabel 1.

Tabel 1. Hasil Analisis Data Persepsi Masyarakat Terhadap Transportasi Publik Trans Sarbagita di Provinsi Bali ditinjau dari Dimensi Kinerja

\begin{tabular}{cccc}
\hline Dimensi & Skor & Rentang Skor & Kategori \\
\hline Kinerja & 10.238 & $9.520-11.759$ & Baik \\
\hline Total & 10.238 & $9.520-11.759$ & Baik \\
\hline
\end{tabular}

Dari tabel 1 menunjukkan bahwa persepsi masyarakat terhadap Trans Sarbagita ditinjau dari dimensi kinerja memperoleh skor sebesar 10.238 yang berada pada rentang skor $9.520-11.759$, sehingga dapat dikategorikan baik. Untuk hasil dari dimensi pelayanan dapat dilihat pada tabel 2.

Tabel 2. Hasil Analisis Data Persepsi Masyarakat Terhadap Transportasi Publik Trans Sarbagita di Provinsi Bali ditinjau dari Dimensi Pelayanan 


\begin{tabular}{cccc}
\hline Dimensi & Skor & Rentang Skor & Kategori \\
\hline Pelayanan & 5.850 & $5.440-6.719$ & Baik \\
\hline Total & 5.850 & $5.440-6.719$ & Baik \\
\hline
\end{tabular}

Dari tabel 2 dapat diketahui bahwa persepsi masyarakat terhadap transportasi publik Trans Sarbagita ditinjau dari dimensi pelayanan mendapatkan skor sebesar 5.850 yang berada direntang skor 5.440 - 6.719, sehingga dapat dikategorikan baik. Selanjutnya untuk dimensi keandalan, hasil yang diperoleh dari pengolahan data dapat dilihat pada tabel 3.

Tabel 3. Hasil Analisis Data Persepsi Masyarakat Terhadap Transportasi Publik Trans Sarbagita di Provinsi Bali ditinjau dari Dimensi Keandalan

\begin{tabular}{cccc}
\hline Dimensi & Skor & Rentang Skor & Kategori \\
\hline Keandalan & 5.774 & $5.440-6.719$ & Baik \\
\hline Total & 5.774 & $5.440-6.719$ & Baik \\
\hline
\end{tabular}

Hasil analisis data berdasarkan tabel 3 dijelaskan bahwa persepsi masyarakat terhadap transportasi publik Trans Sarbagita di Provinsi Bali ditinjau dari dimensi keandalan memperoleh skor sebesar 5.774 berada pada rentang skor 5.440 - 6.719 termasuk ke dalam kategori baik. Kemudian, hasil analisis data yang diperoleh dari dimensi karakteristik produk dapat dilihat pada tabel 4 .

Tabel 4. Hasil Analisis Data Persepsi Masyarakat Terhadap Transportasi Publik Trans Sarbagita di Provinsi Bali ditinjau dari Dimensi Karakteristik Produk

\begin{tabular}{cccc}
\hline Dimensi & Skor & Rentang Skor & Kategori \\
\hline Karakteristik Produk & 2.988 & $2.720-3.359$ & Baik \\
\hline Total & 2.988 & $2.720-3.359$ & Baik \\
\hline
\end{tabular}

Berdasarkan hasil analisis data pada tabel 4 maka dapat dijelaskan bahwa persepsi masyarakat terhadap keberadaan Trans Sarbagita ditinjau dari dimensi karakteristik produk mendapatkan skor sebesar 2.988 yang berada direntang skor 2.720 - 3.359, sehingga dapat dikategorikan baik. Dimensi selanjutnya yaitu dimensi kesesuaian dengan spesifikasi yang memperoleh hasil setelah dilakukannya pengolahan data yaitu seperti pada tabel 5 .

Tabel 5. Hasil Analisis Data Persepsi Masyarakat Terhadap Transportasi Publik Trans Sarbagita di Provinsi Bali ditinjau dari Dimensi Kesesuaian dengan Spesifikasi

\begin{tabular}{cccc}
\hline Dimensi & Skor & Rentang Skor & Kategori \\
\hline Kesesuaian dengan Spesifikasi & 2.819 & $2.720-3.359$ & Baik \\
\hline Total & 2.819 & $2.720-3.359$ & Baik \\
\hline
\end{tabular}

Hasil analisis data berdasarkan tabel 5 dijelaskan bahwa persepsi masyarakat terhadap transportasi publik Trans Sarbagita di Provinsi Bali ditinjau dari dimensi kesesuaian dengan spesifikasi memperoleh skor sebesar 2.819 berada pada rentang skor 2.720 - 3.359 termasuk ke dalam kategori baik. Untuk hasil dari data kuesioner yang diperoleh tentang persepsi masyarakat terhadap Trans Sarbagita ditinjau dari dimensi hasil yaitu seperti pada tabel 6.

Tabel 6. Hasil Analisis Data Persepsi Masyarakat Terhadap Transportasi Publik Trans Sarbagita di Provinsi Bali ditinjau dari Dimensi Hasil

\begin{tabular}{cccc}
\hline Dimensi & Skor & Rentang Skor & Kategori \\
\hline Hasil & 5.075 & $4.160-5.439$ & Kurang Baik \\
\hline Total & 5.075 & $4.160-5.439$ & Kurang Baik \\
\hline
\end{tabular}

Berdasarkan hasil analisis pada tabel 4.6 maka dapat dijelaskan bahwa dimensi hasil memperoleh skor sebesar 5.075 yang berada pada rentang skor 4.160 - 5.439, sehingga dapat dikategorikan kurang baik. Dari pemaparan beberapa hasil data yang telah diperolehmaka hasil yang didapatkan seperti di atas, 
dimana untuk persepsi masyarakat terhadap transportasi publik Trans Sarbagita ditinjau dari dimensi kinerja, pelayanan, keandalan, karakteristik produk dan kesesuaian dengan spesifikasi memperoleh persepsi yang positif, sedangkan persepsi masyarakat ditinjau dari dimensi hasil memperoleh persepsi yang kurang positif.

\section{Pembahasan}

Berdasarkan hasil penelitian yang telah dilakukan, persepsi masyarakat terhadap transportasi publik Trans Sarbagita di Provinsi Bali ditinjau dari dimensi kinerja, pelayanan, keandalan, karakteristik produk, dan kesesuaian dengan spesifikasi menunjukkan hasil yang positif, sedangkan persepsi masyarakat terhadap transportasi publik Trans Sarbagita di Provinsi Bali ditinjau dari dimensi hasil menunjukkan hasil yang kurang positif.Masyarakat menilai bahwa kinerja dari Trans Sarbagita sudah baik. Kinerja Trans Sarbagita dari aspek kecepatan dari Trans Sarbagita dalam mengantarkan penumpang sampai pada tempat tujuan tergolong baik, karena masyarakat beranggapan bahwa Trans Sarbagita sudah mengatur waktu keberangkatan dengan tepat sehingga penumpang sampai pada tempat tujuan dengan tepat waktu. Hal tersebut sejalan dengan penelitian Ayu, Sriastuti, \& Armaeni (2016), bahwa waktu tempuh dan kecepatan dari Trans Sarbagita sudah memenuhi standar kualitas. Kinerja Trans Sarbagita dari aspek akselerasi dinilai sudah baik karena Trans Sarbagita dapat mengatur kecepatan dalam berkendara. Kinerja Trans Sarbagita dari aspek sistem kemudi dinilai sudah baik, karena sopir dari Bus Trans Sarbagita mengantarkan penumpang sesuai dengan trayek yang telah ditetapkan oleh Trans Sarbagita, yang dimana trayek tersebut diatur di dalam Keputusan Gubernur Bali Nomor 1186/03-F/HK/2010.

Masyarakat juga menilai kinerja Trans Sarbagita dari aspek kenyamanan sudah baik. Pemerintah meluncurkan program Trans Sarbagita dengan memperhatikan kenyamanan dari penumpangnya, seperti Bus yang digunakan oleh Trans Sarbagita adalah bus yang bersih dan layak pakai. Kenyamanan dijadikan prioritas utama karena tujuan utama diluncurkan program ini untuk mengatasi kemacetan yang terjadi di Daerah Sarbagita. Dengan menjadikan kenyamanan sebagai prioritas utama maka masyarakat akan beralih ke transportasi publik dibandingkan transportasi pribadi. Hal tersebut juga diindikasi oleh penelitianParamartha, Aryawan, \& Hermawati (2019), bahwa masyarakat merasa puas terhadap kenyamanan yang diberikan oleh Trans Sarbagita seperti, kebersihan bus, keamanan bus, pelayanan bus, dan tarif yang diberlakukan oleh Trans Sarbagita.

Pelayanan dari Trans Sarbagita juga tergolong sudah baik, masyarakat yang belum pernah menggunakan Trans Sarbagita tidak memberikan penilaian yang buruk terhadap pelayanan Trans Sarbagita, karena Trans Sarbagita tidak pernah mengakibatkan kecelakaan pada penumpang dan tidak pernah mengantar penumpang dengan tidak selamat, maka dari ini masyarakat beranggapan bahwa pelayanan dari Trans Sarbagita sudah baik. Pelayanan yang baik diberikan oleh Trans Sarbagita dapat menjadikan Trans Sarbagita terkesan baik dikalangan masyarakat. Menurut penelitian yang dilakukan oleh Hardaningtyas (2018)bahwa pelayanan dibidang jasa dapat menjadi sukses apabila ditunjang oleh kinerja para pengemudi transportasiketika memberikan pelayanan terhadap masyarakat.Dengan adanya citra produk yang baik terhadap Trans Sarbagita maka masyarakat akan lebih percaya dan berminat dalam menggunakan transportasi publik Trans Sarbagita.

Tidak hanya dari dimensi kinerja dan pelayanan, masyarakat juga beranggapan keandalan dari Trans Sarbagita dari aspek kepuasan konsumen sudah baik. Fasilitas yang diberikan oleh Bus Trans Sarbagita seperti fasilitas AC (Air Conditioner) sangat tepat diberikan di dalam bus tersebut, karena Daerah Sarbagita yang terkenal dengan kemacetan dan daerah yang panas dengan terik matahari dan polusi kendaraan bermotor tersebut sangat berguna dalam memberikan kepuasan bagi penumpang Trans Sarbagita agar tetap merasa nyaman.

Fasilitas yang diberikan di dalam Trans Sarbagita juga tidak mempengaruhi tarif dari transpotasi tersebut. Tarif yang tergolong rendah dan dapat dijangkau oleh masyarakat dari segala kalangan. Terlebih lagi dengan dikeluarkannya Peraturan Gubernur Bali Nomor 112 tahun 2018 tentang perubahan tarif dari Trans Sarbagita untuk penumpang dari kalangan pelajar/ mahasiswa yang berubah menjadi gratis sangat meringankan beban pelajar/ mahasiswa yang ingin menggunakan transportasi publik Trans Sarbagita. Trans Sarbagita sangat memikirkan bagaimana kenyamanan dari penumpang, sehingga tidak hanya fasilitas AC (Air Conditioner) saja yang diberikan di Bus tersebut, Trans Sarbagita juga dilengkapi oleh kursi yang nyaman, bus yang bersih, tabung pemadam kebakaran, dan alat pemecah kaca. Tidak hanya sampai disana, fasilitas yang diberikan oleh Trans Sarbagita memiliki inovasi, seperti adanya pintu darurat untuk penumpang jika terjadi sesuatu di dalam bus tersebut. Transportasi publik Trans Sarbagita ini tidak memiliki kesan yang buruk di dalam masyarakat dari segi kinerja, pelayanan, keandalan, karakteristik produk dan kesesuaian dengan spesifikasi.

Hanya saja masih ada nilai kurang di dalam kinerja Bus tersebut, seperti kedatangan bus yang tidak tepat waktu sehingga masyarakat menunggu lama untuk kedatangan bus. Hal tersebut sesuai dengan 
penelitian yang dilakukan Avionto \& Dindayanti (2020) bahwa jadwal operasional bus sering tidak sesuai dengan jadwal dan Trans Sarbagita juga sering mengalami keterlambatan kedatangan. Hal serupa juga sejalan dengan penelitian Putrayasa \& Maharani (2014) menyatakan bahwa ketepatan waktu kedatangan Bus Trans Sarbagita Rute Kota - GWK dianggap tidak efektif karena Bus Trans Sarbagita Rute Kota - GWK sering terkena kemacetan di Patung Dewa Ruci sehingga membuat perjalanan mereka lebih lama dibandingkan menggunakan kendaraan pribadi.

Kedatangan bus Trans Sarbagita yang terlambat juga dikarenakan oleh keadaan lalu lintas di Daerah Sarbagita yang padat. Dengan kedatangan Bus yang kerap terlambat, maka masyarakat cenderung menunggu lama di halte penjemputan yang termasuk kecil dan tidak terlalu nyaman. Hal demikian juga disampaikan dari hasil penelitian Yuphardi \& Waisnawa (2015) bahwa halte dari Trans Sarbagita kurang nyaman karena ramp yang sangat curam, handrail yang kurang sesuai. Untuk itu masyarakat berharap kinerja dari Trans Sarbagita lebih ditingkatkan lagi agar minat masyarakat juga semakin tinggi dalam menggunakan Trans Sarbagita.

Selain keterlambatan kedatangan bus, menurut Saragih \& Nugroho (2015) dalam penelitiannya menyatakan bahwa Jalur Wisata Denpasar - GWK sama sekali tidak memiliki akses transportasi publik untuk dikonsumsi masyarakat, jadi masayarakat cenderung menggunakan transportasi pribadi. Hal tersebut juga mengurangi minat masyarakat di Daerah Denpasar. Dengan itu pemerintah harus melakukan evaluasi untuk meningkatkan minat masyarakat. Jika minat masyarakat dalam menggunakan transportasi publik Trans Sarbagita semakin tinggi maka tujuan utama dari Trans Sarbagita akan terealisasikan, yaitu mengurangi kemacetan di Daerah Sarbagita.

Berdasarkan beberapa persepsi dari masyarakat yang tinggal di Daerah Denpasar, Badung, Gianyar dan Tabanan tentang transportasi publik Trans Sarbagita, dimensi yang mempengaruhi masyarakat terhadap persepsinya mengenai suatu objek atau suatu produk yaitu sesuai dengan teori yang dikemukakan oleh Assael (2001), dimana persepsi masyarakat mengenai suatu produk dapat dilihat dari dimensi kinerja, pelayanan, keandalan, karakteristik produk, kesesuaian dengan spesifikasi dan hasil.

Dinilai dari dimensi kinerja Trans Sarbagita itu sendiri sudah baik dan masyarakat berharap agar pemerintah tetap meningkatkan kinerja dari Trans Sarbagita agar masyarakat lebih merasa nyaman dan aman menggunakan Trans Sarbagita.Dinilai dari aspek pelayanan Trans Sarbagita tersebut, masyarakat memiliki persepsi yang positif terhadap pelayanannya. Dalam penelitian yang dilakukan Sriasih \& Martiningsih (2017), menyatakan bahwa kepuasan konsumen juga dipengaruhi dengan pelayanan Trans Sarbagita seperti bukti fisik, keandalan, daya tanggap, keamanan, dan empati dari Trans Sarbagita.

Semoga pihak Trans Sarbagita tetap memberikan pelayanan yang terbaiknya dan selalu mendengarkan masukan dari masyarakat sekitar agar Trans Sarbagita tetap menjadi transportasi publik terbaik di Bali. Dari aspek keandalannya sendiri pun sudah dinilai baik oleh masyarakat, semoga fasilitas yang diberikan oleh Trans Sarbagita selalu meningkat sehingga dapat meningkatkan kepuasan penumpangnya. Untuk aspek karakteristik produk dari Trans Sarbagita sudah baik, pihak Trans Sarbagita selalu memperhatikan inovasi-inovasi yang terbaru untuk transportasi publik tersebut, semoga kedepannya inovasi yang lebih modern dapat dituangkan di dalam Trans Sarbagita. Selanjutnya, dinilai dari aspek kesesuaian dengan spesifikasi Trans Sarbagita sudah baik karena sudah mengikuti Standar Pelayanan Minimal dalam melakukan seluruh kegiatan operasionalnya.

Aspek terakhir yang dinilai yaitu aspek hasil, dimana hasil dari adanya Trans Sarbagita dinilai oleh masyarakat masih kurang baik, karena tujuan dari adanya Trans Sarbagita belum sepenuhnya terealisasi.Semoga pemerintah bersama pihak Trans Sarbagita dapat merealisasikan tujuan utama dari Trans Sarbagita itu sendiri yaitu mengurangi kemacetan dan mengurangi volume kendaraan di jalanan. Tujuan tersebut dapat direalisasikan dengan meningkatkan aspek-aspek sebelumnya seperti kinerja, pelayanan, keandalan, karakteristik produk dan kesesuaian dengan spesifikasi.

Jika aspek tersebut sudah ditingkatkan, maka minat masyarakat dalam menggunakan Trans Sarbagita akan meningkat, dengan meningkatnya minat masyarakat tersebut maka tujuan utama dari Trans Sarbagita dapat terealisasikan dengan baik.Pemerintah juga harus memberikan penyuluhan terhadap pentingnya penggunaan transportasi umum demi menciptakan membantu menciptakan kondisi lalu lintas yang kondusif dan tertata baik.

\section{Simpulan dan saran}

\section{Simpulan}


Berdasarkan hasil analisis data dan pembahasan yang telah dipaparkan sebelumnya, maka peneliti dapat menarik kesimpulan yaitu persepsi masyarakat terhadap transportasi publik Trans Sarbagita di Provinsi Bali ditinjau dari dimensi kinerja memperoleh skor sebesar 10.238 yang berada pada rentang skor 9.520 - 11.759, sehingga dapat dikategorikan baik. Persepsi masyarakat terhadap Trans Sarbagita ditinjau dari dimensi pelayanan mendapatkan skor sebesar 5.850 yang berada direntang skor 5.440 - 6.719, sehingga dapat dikategorikan baik. Persepsi masyarakat terhadap Trans Sarbagita ditinjau dari dimensi keandalan memperoleh skor sebesar 5.774 berada pada rentang skor 5.440 - 6.719 termasuk ke dalam kategori baik.

Persepsi masyarakat terhadap transportasi publik Trans Sarbagita di Provinsi Bali ditinjau dari dimensi karakteristik produk mendapatkan skor sebesar 2.988 yang berada direntang skor 2.720 - 3.359, sehingga dapat dikategorikan baik. Persepsi masyarakat terhadap transportasi publik Trans Sarbagita di Provinsi Bali ditinjau dari dimensi kesesuaian dengan spesifikasi memperoleh skor sebesar 2.819 berada pada rentang skor 2.720 - 3.359 termasuk ke dalam kategori baik.

Persepsi masyarakat terhadap transportasi publik Trans Sarbagita di Provinsi Bali ditinjau dari dimensi hasil memperoleh skor sebesar 5.075 yang berada pada rentang skor 4.160 - 5.439, sehingga dapat dikategorikan kurang baik. Peneliti dapat menarik kesimpulan bahwa persepsi masyarakat terhadap transportasi publik Trans Sarbagita ditinjau dari dimensi kinerja, pelayanan, keandalan, karakteristik produk, dan kesesuaian dengan spesifikasi memiliki persepsi yang baik sedangkan ditinjau dari dimensi hasil memiliki persepsi yang kurang baik.

\section{Saran}

Berdasarkan hasil, pembahasan, dan simpulan yang telah dipaparkan sebelumnya, maka peneliti mengajukan beberapa saran yaitu bagi Dinas Perhubungan Provinsi Bali UPT. Trans Sarbagita disarankan meningkatkan sarana dan prasarana untuk menunjang keberhasilan dari Trans Sarbagita, seperti dibuatkannya jalur khusus untuk melajunya Trans Sarbagita. Meningkatkan inovasi-inovasi yang ada di bus Trans Sarbagita untuk menarik minat masyarakat, seperti pembuatan member card yang nantinya dapat diberikan ketentuan misalnya penumpang sudah menggunakan Trans Sarbagita sebanyak 10 kali yang tercatat di dalam member card tersebut akan mendapatkan gratis menggunakan Trans Sarbagita dalam sekali perjalanan. Kemudian dengan memindahkan halte-halte penjemputan yang dirasa kurang efektif ke tempat yang lebih strategis.

Bagi peneliti lain penelitian ini disarankan lebih dikembangkan lagi, karena di dalam penelitian ini hanya meneliti persepsi masyarakat, sehingga untuk peneliti selanjutnya dapat menambah objek penelitian misalnya dengan membandingkan Trans Sarbagita dengan Transportasi publik lainnya.

\section{Daftar Rujukan}

Adisasmita, S. A. (2011). Jaringan Transportasi, Teori dan Analisis. Yogayakarta: Graha Ilmu.

Assael, H. (2001). Customer Behavior 6th Edition. New York: Thomson-Learning.

Avionto, B. N., \& Dindayanti, R. (2020). Kualitas Pelayanan Angkutan UMUM Trans Sarbagita Koridor I (Kota-GWK) Tahun 2018. Jurnal Ilmiah Indonesia, 5(1), 17-27.

Ayu, D., Sriastuti, N., \& Armaeni, N. K. (2016). Evaluasi Kinerja Pengoperasian Angkutan Pengumpan (Feeder) Trans Sarbagita Tp 02 Kota Denpasar. Paduraksa, 5(1), 1-9.

Budianayasa, I. P., \& Wairocana, I. G. N. (2018). Efektivitas Standar Pelayanan Angkutan Trans Sarbagita Berdasarkan Peraturan Gubernur Bali Nomor 11 Tahun 2011. Journal Ilmu Hukum, 6(3), 1-15.

Hardaningtyas, R. T. (2018). Persepsi Masyarakat Terhadap Penggunaan Transportasi Online (Grab) Di Malang. INOBIS: Jurnal Inovasi Bisnis Dan Manajemen Indonesia, 2(1), 42-58. https://doi.org/10.31842/jurnal-inobis.v2i1.60

Irianto, A. (2004). Statistik Konsep Dasar dan Aplikasinya. Jakarta: Prenada Media.

Paramartha, K. W., Aryawan, I. G. M. O., \& Hermawati, P. (2019). TRANSPORTASI BUS TRANS SARBAGITA ( Studi Kasus: Koridor I, Kota - GWK ). Prosiding Seminar Nasional Ketekniksipilan Bidang Vokasional, 1(1), 1-5.

Putra, I. G. A. B. A. (2016). Studi Evaluasi Program Bus Trans Sarbagita Pemerintah Provinsi Bali. Kebijakan Dan Manajemen Publik, 4(1), 1-9. Retrieved from http://journal.unair.ac.id/download-fullpaperskmp1c43603fb3full.pdf

Putrayasa, A., \& Maharani, S. (2014). Efektifitas Bus Trans Sarbagita dalam Mengurangi Kemacetan di Kota Denpasar dan Kabupaten Badung. Sosial Dan Humaniora,1(3), 169-184.

Saragih, E., \& Nugroho, S. (2015). Makna Ketersediaan Trans Sarbagita Jalur Denpasar-Gwk Bagi Pariwisata Bali. Jurnal Destinasi Pariwisata, 3(2), 7-13. https://doi.org/10.24843/JDEPAR.2015.v03.i02.p02

Sihotang, D. E. M. (2015). Pengaruh Status Sosial Ekonomi Masyarakat Kota Denpasar Terhadap Pemilihan Trans Sarbagita Sebagai Moda Transportasi (Studi di Koridor I dan II). 1(3). 
Sriasih, N. N. R., \& Martiningsih, N. G. A. G. E. (2017). KUALITAS PELAYANAN ANGKUTAN UMUM TRANS SARBAGITA SEBAGAI SARANA. Prosiding Seminar Nasional Perencanaan Pembangunan Inklusif Desa Kota, 1(4), 421-424.

Surung, Wulandari, D. P. N., \& Arka, S. (2013). Faktor-Faktor yang Mempemharuhi Intensitas (Studi Kasus Mahasiswa Universitas Udayana). E-Jurnal EP Unud, 2(12), 555-563.

Tamin, O. z. (1995). Perencanaan dan Pemodelan Transportasi. Bandung: ITB.

Tunjungsari, K. R., Setiawan, I. P. N., Wijaya, I. G. A. S., Tonglo, A. J. D. R., \& Apriawan, K. A. (2019). Pelayanan Transportasi Umum Bus Trans Sarbagita Bagi Masyrakat dan Pariwisata Kota Denpasar. Jurnal Sains Terapan Pariwisata, 4(1), 1-11.

Utama, P. A., \& Handayeni, K. D. M. E. (2019). Arahan Peningkatan Penggunaan Moda Bus Trans Sarbagita pada Koridor 1 di Kota Denpasar. Jurnal Penataan Ruang, 14(1), 6-11.

Widhyastuti, A. A. M., Pascarani, N. N. D., \& Yudharta, I. P. D. (2016). Implementasi Program Trans Sarbagita dalam Pengembangan Transportasi Publik di Bali. Citizen Charter, 1(1), 1-7.

Wulandari, N. P. C., \& Sudiana, K. (2011). Analisis Tingkat Efektivitas Trans Sarbagita Sebagai Transportasi Publik di Provinsi Bali. E-Jurnal EP,7(11):2490-2517, 2490-2517.

Yuphardi, T. H., \& Waisnawa, I. M. J. (2015). Studi Aksesibilitas Fasilitas Publik Halte Trans Sarbagita terhadap Penyadang Disabilitas. Segara Widya, 3(30), 377-388. Retrieved from https://jurnal.isidps.ac.id/index.php/segarawidya/article/download/203/120/ 